\title{
Tradisi Dui Menre Pada Suku Bugis di Kabupaten Wajo: Kajian Hukum Islam
}

\author{
Ekawati \\ Jurusan Akhwalus Syakhsiyyah, Fak. Syariah dan hukum \\ IAI As'adiyah Sengkang \\ Jl. Veterean No. 46 Lapongkoda, Tempe, Kabupaten Wajo, Sulawesi Selatan \\ E-mail: hamzahekawati@gmail.com
}

Diterima : 3 September 2019: Direvisi 31 Desember 2019; Diterbitkan : 31 Desember 2019

\begin{abstract}
Abstrak
Penelitian ini membahas tentang Tradisi dui menre pada Suku Bugis di Kabupaten Wajo (Kajian Hukum Islam) bertujuan untuk mengetahui kedududukan dui menre dan hukum pernikahan adat bugis di Kabupaten Wajo. Penelitian ini menggunakan metode (library research) dan (field research) dan serta artikel-artikel yang di anggap mempunyai kaitan masalah yang akan di teliti mengenai pemberian dui menre. Penelitian ini melalui tekhik wawancara berdasarkan data hasil wawancara yang ada penulis berusaha menarik kesimpulan yang lebih umum. Peneliti ini dilakukan di Kantor Urusan Agama Kabupaten Wajo, Toko Agama dan Toko Adat. Dalam hasil penelitian ini dapat dikemukakan bahwa ternyata masyarakat bugis khususnya di Kabupaten Wajo menganggap bahwa pemberian dui menre adalah tradisi wajib, yang diberikan oleh pihak laki-laki kepada pihak perempuan yang fungsinya digunakan sebagai biaya uantuk melaksanakan pesta pernikahan, dan memberikan rasa hormat bagi keluarga pihak perempuan. Kedudukan dui menre dalam pernikahan adat bugis salah satu syarat utama, karna jika tidak ada dui menre maka tidak ada pula pernikahan. Islam tidak mengatur mengenai ketentuan dui menre akan tetapi hukumnya mubah.
\end{abstract}

Kata Kunci: Adat, Dui menre, Pernikahan, Sulawesi Selatan, Tradisi Bugis

\section{Abstract}

This study discusses the dui menre Tradition in Bugis Tribe in Wajo District aims to determine the position of dui Menre and the law of customary marriage in Bugis in Wajo Regency. This research uses the method (library research) and (field research) and as well as articles that are considered to have related problems that will be examined regarding the administration of $d u i$ menre. This research through interview techniques based on existing interview data, the author tries to draw more general conclusions. The researcher was conducted at the Wajo District Office of Religious Affairs, Religious Stores and Traditional Stores. In the results of this study, it can be stated that apparently the Bugis community, especially in Wajo District considers that the giving of dui menre is a compulsory tradition, which is given by men to women whose function is used as a cost for holding a wedding, and gives respect to the family of the party women. The position of dui menre in Bugis customary marriage is one of the main requirements, because if there is no dui menre then there is no marriage. Islam does not regulate the provisions of dui menre but the law changes.

Keywords: Adat, Dui menre, Marriage, South Sulawesi, Bugis Tradition 


\section{PENDAHULUAN}

Pernikahan menurut Undang-Undang Nomor 1 Tahun 1974 tentang perkawinan, adalah ikatan lahir batin antara seorang pria dengan seorang wanita untuk hidup berumah tangga yang bahagia dan kekal berdasarkan ketuhanan Yang Maha Esa.

Sebagaimana firman Allat swt dalam Q.S. Al-Qashash/27:

"Berkatalah dia (Syu'aib): "Sesungguhnya aku bermaksud menikahkan kamu dengan salah seorang dari kedua anakku ini, atas dasar bahwa kamu bekerja denganku delapan tahun dan jika kamu cukupkan sepuluh tahun maka itu adalah (suatu kebaikan)”.

Sejalan dengan yang dikemukakan oleh Wirijono Prodjodikoro dalam bukunya, bahwa apabila seorang perempuan dan laki-laki berjanji untuk menikah maka mereka akan taat pada peraturan-peraturan hukum yang berlaku mengenai hak-hak kewajiban masing-masing pihak selama hidup bersama dan mengenai kedudukan anak-anak keturunnanya kelak dalam masyarakat. Pernikahan tidak hanya mempersatukan satu pasangan, akan tetapi mengikatkan tali perjanjian yang suci atas nama Allah, bahwa kedua mempelai berniat membangun rumah tangga yang sakinah.

Islam sangat menganjurkan pernikahan karena pernikahan mempunyai nilai-nilai keagamaan sebagai wujud ibadah kepada Allah swt, dan mengikuti sunnah Nabi di samping itu juga memenuhi nilai-nilai kemanusiaan untuk naluri hidup manusia guna melestarikan keturunan, mewujudkan ketentraman hidup, dan menumbuhkan rasa kasih sayang dalam hidup bermasyarakat.

Menurut adat suku bugis, sebelum prosesi pernikahan dilaksanakan ada beberapa tahap yang harus dilalui oleh calon mempelai laki-laki. Salah satu di antaranya adalah proses peminangan dari pihak keluarga calon mempelai laki-laki kepada pihak calon mempelai perempuan, sekaligus penentuan pemberian uang panaik yang akan diberikan oleh calon mempelai laki-laki kepada pihak keluarga calon mempelai wanita apabila lamaran tersebut diterima.

Namun dari zaman ke zaman adat dui menre mulai beradaptasi terus ke bawah lapisan kasta masyarakat secara menyeluruh dan menjadi persyaratan mutlak pada laki-laki untuk ingin meminang seorang perempuan.

Besaran dui menre yang berlaku saat ini dipengaruhi oleh status sosial yang melekat pada orang yang akan melaksanakan pernikahan dengan baik dari pihak laki-laki maupun dari pihak perempuan, tingkat pendidikan, strata sosial, faktor kekayaan, faktor popularitas, dan apalagi jika orang tersebut berketurunan ningrat atau dara biru, semakin tinggi derajat semua status tersebut maka semakin tinggi pula permintaan uang panai'nya. Bahkan hal persyaratan utamanya atau menjadi pembahasan pertama pada pelamaran sebelum 
melangsungkan pernikahan adalah besaran "Uang Panai (dui menre).

Kabupaten wajo merupakan salah satu kabupaten di Sulawesi Selatan yang termasuk tinggi uang panainya (Dui Menrenya), masyarakat Bugis Wajo beranggapan bahwa kewajiban atau keharusan memberikan dui menre sama seperti kewajiban memberikan mahar. Hal ini terjadi karena antara uang panaik (dui menre) dan mahar adalah merupakan satu kesatuan yang tidak dapat dipisahkan. Seorang calon suami yang memberikan dui menre kepada pihak keluarga calon istri bukan berarti secara langsung telah memberikan mahar. Karena dui menre tersebut belum termasuk mahar. Sehingga jika uang panaik tidak ada maka perkawinan pun tidak akan pernah terjadi.

Saat ini pemahaman sebagian besar masyarakat suku bugis tentang pengertian mahar (Sompa) dan dui menre masih banyak yang keliru. Masih ada segelintir orang yang menyamakan kedudukan keduanya, padahal kedua hal tersebut berbeda.

Uang panai (dui menre) yang diberikan oleh calon suami jumlahnya lebih banyak dari pada mahar. Adapun kisaran jumlah dui mernre dimulai dari 50 juta, dan bahkan ratusan juta. Hal ini dapat dilihat ketika prosesi akad nikah yang hanya menyebutkan mahar dalam jumlah yang kecil.

Penyebab tingginya jumlah dui menre yang ditentukan oleh keluarga calon mempelai perempuan disebabkan oleh beberapa faktor, di antaranya adalah status sosial calon istri serta tinggi rendahnya jenjang pendidikan calon istri.

Namun pada umumnya pelaksanaan acara pernikahan adat di Indonesia dipengaruhi oleh beberapa bentuk dan sistem pernikahan adat setempat yang dipertahankan oleh masyarakat yang bersangkutan.

Berdasarkan hal tersebut, maka tujuan kajian ini adalah untuk mengetahui kedudukan, fungsi, serta tinjauan hukum Islam terhadap dui menre dalam perkawinan adat Bugis di Kabupaten Wajo.

\section{METODE PENELITIAN}

Penelitian ini menggunakan metode (library research) dan (field research) dan serta artikel-artikel yang di anggap mempunyai kaitan masalah yang akan di teliti mengenai pemberian dui menre. Penelitian ini melalui tekhik wawancara berdasarkan data hasil wawancara yang ada penulis berusaha menarik kesimpulan yang lebih umum. Peneliti ini dilakukan di Kantor Urusan Agama Kabupaten Wajo, Toko Agama dan Toko Adat di Kabupaten Wajo. 


\section{HASIL DAN PEMBAHASAN}

\section{Profil Masyarakat Bugis Wajo}

Kabupaten Wajo dulunya terdiri dari 10 kecamatan, akan tetapi sejak tahun 2000 terjadi pemekaran hingga saat ini terdapat 14 kecamatan, yaitu: Belawa, Bola, Gilireng, Keera, Majauleng, Maniangpajo, Pammana, Penrang, Pitumpanua, Sabbangparu, Sajoanging, Takkalalla, Tana Sitolo, dan Tempe.

\section{A. Visi dan Misi}

Visi yang didefinisikan sebagai gambaran kesuksesan yang hendak dicapai dalam kurun waktu tertentu, kedua adalah misi yang menyatakan tugas yang ingin dikerjakan sebagai pengejawantahan keberadaan visi, kemudian dirumuskan dalam Renstra Kabupaten Wajo, sebagaimana dapat dilihat sebagai berikut: terciptanya pemerintahan demokratis, beriman dan bertakwa, bebas dari kolusi korupsidirn nepotisme (KKN), dan berwibawa dalam melayani masyarakat serta menjadi kreatif produktif dan mandiri menuju terciptanya Kabupaten Wajo sebagai salah satu pusat agribisnis di Sulawesi Selatan. Adapun misi Kabupaten Wajo adalah:

1. Meningkatkan kualitas sumberdaya manusia dari segala lapisan dan profesi.

2. Menyelenggarakan pemerintahan sebagai pelayan kepentingan masyarakat dalam rangka pemberdayaan masyarakat.

3. Menciptakan koneksitas yang sinergis antar daerah / wilayah (pola kemitraan / jaringan)

4. Mengoptimalkan pemanfaatan sumberdaya pembangunan (alam, teknologi, modal, sosial) demi kepentingan masyarak

5. Mengembangkan ekonomi perdesaan yang berbasis pada pertanian dalam arti luas.

6. Menjadikan Wajo sebagai Daerah Tujuan Wisata di Sulawesi Selatan

7. Mengupayakan peningkatan $\mathrm{PAD}$ melalui intensifikasi, ekstensifikasi dan diversifikasi sumber - sumber pendapatan

8. Mengembangkan pusat - pusat pelayanan, termasuk pusat pelayanan industri

9. Pengembangan peternakan rakyat khususnya sapi, kambing, ayam buras dan itik

10. Pengurusan peralatan pengembangan mekanisasi pertanian dan pembinaan organisasi tingkat petan

\section{B. Letak Geografis}

Secara geografis, Kabupaten Wajo terletak pada $3{ }^{\circ} 39^{\prime}-4^{\circ} 16^{\prime}$ Lintang Selatan dan $119^{\circ} 53^{\prime}-120^{\circ} 27^{\prime}$ Bujur Timur. Sebagian besar wilayahnya berupa dataran rendah hingga 
dataran rendah bergelombang dengan ketinggian wilayah 0-520 Mdpl. Hanya sebagian kecil yang berupa perbukitan di bagian utara. Bagian timur berupa dataran rendah dan pesisir teluk Bone, termasuk pulau-pulau pasir di perairan teluk bone. Sedangkan bagian barat merupakan dataran aluvial danau tempe-sidenreng Rappang.

\section{Iklim}

Kabupaten Wajo di Sulawesi Selatan wilayah Indonesia mempunyai iklim tropis dengan 3 musim yaitu kemarau, hujan dan pancaroba hal tersebut mempunyai pengaruh langsung terhadap aktivitas masyarakat di Kabupaten Wajo.

\section{Penduduk, Mata Pencaharian dan Perekonomian}

Pada umumnya, jumlah penduduk laki-laki di seluruh kecamatan di Kabupaten Wajo lebih rendah daripada jumlah penduduk wanita. Rata-rata sexratio adalah 88, dan hanya beberapa kecamatan yang memiliki sex-ratio di atas 90. Kecamatan yang memiliki sex ratio paling rendah di Kabupaten Wajo adalah Kecamatan Sabangparu, dengan jumlah penduduk pria 11.985 jiwa, jumlah penduduk wanita 14.474 jiwa (total penduduk tahun 2001 adalah 26.459). Sebagian besar penduduk (98 \%) Kabupaten Wajo adalah beragama lslam. Hanya sebagian kecil dari total jumlah penduduk yang memeluk agama Protestan, Katolik, Hindu, dan Budha.

Kondisi ketenagakerjaan di Kabupaten Wajo menunjukkan kecenderungan dominasi penduduk yang bekerja di sektor primer, yaitu sektor pertanian, perikanan, peternakan, dan kehutanan. Dari seluruh wilayah Kabupaten Wajo, hanya 45 orang yang bekerja di sektor jasa kemasyarakatan. Walaupun demikian data ketenagakerjaan ini belumlah mencerminkan struktur ketenagakerjaan yang riil di Kabupaten Wajo, karena kecilnya nilai sampling yang digunakan (di bawah $1 \%$ dari total populasi). Data tersebut lebih didasarkan pada data resmi ketenagakerjaan yang terdaftar di Dinas PMD dan Tenaga Kerja. Seperti juga perubahan yang terjadi di Indonesia pada umumnya, di Kabupaten Wajo pun terjadi pergeseran konsentrasi ketenagakeriaan, dimana perbandingan antara tahun 1990 dan 1999 menunjukkan jumlah tenaga kerja di sektor pertanian mengalami penurunan. Di lain pihak, di sektor perdagangan dan konstruksi mengalami peningkatan jumlah tenaga kerja. Sektor jasa dan sektor pengolahan merupakan sektor lain setelah sektor pertanian yang memiliki jumlah tenaga kerja yang relatif lebih tinggi dibandingkan sektor lainnya. Penduduk usia produktif di Kabupaten Wajo dari tahun 1990 sampai tahun 1999 mengalami peningkatan jumlah. Akan tetapi pada umumnya hanya kurang lebih setengah dari penduduk usia kerja yang termasuk dalam angkatan kerja. Untuk tahun 1990, persentase angkatan kerja terhadap penduduk usia kerja di Kabupaten Wajo lebih tinggi dari rata-rata seluruh kabupaten (Sulawesi Selatan). 
Tetapi pada tahun 1999 terjadi sebaliknya.

Struktur perekonomian Kabupaten Wajo masih didominasi oleh sektor pertanian, termasuk di dalamnya pertanian tanaman pangan, perkebunan, dan perikanan. Walau sektor ini masih dominan, kontribusi sektor ini kian berkurang setiap tahunnya. Sebaliknya sejak tahun 1998 sektor perdagangan, hotel, dan restoran mulai menunjukkan kontribusinya secara signifikan. Sektor lain yang cukup besar kontribusinya adalah pertambangan dan penggalian, walau laju pertumbuhannya masih bersifat fluktuatif.

\section{Pernikahan dan Dui Menre dalam Masyarakat Bugis Wajo}

\section{A. Pengertian Pernikahan dan Rukun Nikah}

Kata nikah berasal dari bahas arab nikaahun yang merupakan masdar atau kata asal dari kata nakaha. Sinonimnya tazawwaja kemudian diterjemahkan dalam Bahasa Indonesia sebagaimana yang disebut perkawinan. Sedangkan secara bahasa kata nikah berarti adhdhammu wattadakhul (bertindih dan memasukkan) oleh karena itu menurut kebiasaan arab, pergesekan rumpun pohon seperti pohon bambu akibat tiupan angin diistilahkan dengan tanakahatil asyjar (rumpun pohon itu sedang kawin), karena tiupan angin itu terjadi pergesekan dan masuknya rumpun yang satu keruang yang lain.

Ulama golongan syafi'iyah memberikan definisi nikah adalah, akad/perjanjian yang mengandung maksud membolehkan hubungan kelamin dengan menggunakan lafadz na-kaha atau za-wa-ja atau yang semakna dengan keduanya.

Sejalan dengan pendapat di atas, ulama Hanafiyah juga memberikan definisi sebagai berikut, akad yang ditentukan untuk memberi hak kepada seorang laki-laki menikmati kesenangan dengan seorang perempuan secara sengaja.

Hukum menikah dalam Islam pada umumnya adalah sunnah Muakad, tetapi bisa berubah sesuai dengan kondisi dan niat sesorang. Dalam Kompilasi Hukum Islam (KHI) di Indonesia disebutkan bahwa: Perkawinan menurut hukum Islam adalah "akad yang sangat kuat atau miitsaqon gholiidhon untuk mentaati perintah Allah dan melaksanakan merupakan ibadah.

Setiap perbuatan hukum harus memenuhi dua unsur yaitu rukun dan syarat, jika kedua unsur ini tidak terpenuhi maka perbuatan itu dianggap tidak sah menurut hukum. Tentang jumlah rukun nikah Imam Malik dan Syafi’i menyebutkan lima, yaitu calon pengantin laki- laki, calon pengantin perempuan, wali, dua orang saksi dan sighat akad nikah, sedangkan menurut Hanafiyah hanya ada satu yaitu ijab dan qobul (akad yang dilakukan oleh pihak wali perempuan dan calon pengantin laki-laki).

Islam sangat menganjurkan pernikahan karena termasuk sebagai wujud ibadah kepada Allah swt, dan mengikuti sunnah Nabi di samping itu juga mempunyai nila-nilai 
kemanusiaan untuk memenuhi naluri hidup manusia guna melestarikan keturunan, mewujudkan ketenteraman hidup, dan menumbuhkan rasa kasih sayang dalam hidup bermasyarakat.

Dalam pandangan Islam, pernikahan merupakan qudrat dan irodat Allah dalam penciptaan alam semesta. Sesuai firman Allah SWT dalam surah Q.S. An-Nisaa'/4:1

Hai sekalian manusia, bertakwalah kepada Tuhan-mu yang telah menciptakan kamu dari seorang diri, dan dari padanya Allah menciptakan isterinya; dan dari pada keduanya Allah memperkembang biakkan laki-laki dan perempuan yang banyak. Dan bertakwalah kepada Allah yang dengan (mempergunakan) namaNya kamu saling meminta satu sama lain, dan (peliharalah) hubungan silaturrahim. Sesungguhnya Allah selalu menjaga dan mengawasi kamu.

\section{Hadis Nabi SAW:}

Wahai para pemuda, siapa saja diantara kalian yang telah memiliki kemampuan untuk menikah, hendaklah dia menikah; karena menikah lebih menundukkan pandangan dan lebih menjaga kemaluan. Adapun bagi siapa saja yang belum mampu menikah, hendaklah ia berpuasa; karena berpuasa itu merupakan peredam (syahwat)nya”.

\section{B. Pengertian, Sejarah dan Stratifikasi Dui Menre}

\section{Pengertian Dui Menre}

Penikahan merupakan sebagai ikatan (akad) perkawinan dengan ketentuan hukum dan ajaran Islam, menurut masyarakat Bugis di Kabupaten Wajo saat ini hukum syariat tidak hanya menjadi bahan acuan dalam pernikahan akan tetapi yang paling berpengaruh adalah adat/tradisi yang berperan penting dalam pernikahan. Salah satu pembahasan utama dalam perencanaan pernikahan adalah dui menre.

Dui menre dalam bahasa bugis atau bahasa makassarnya Uang Pannaik adalah sejumlah uang yang wajib diserahkan oleh calon mempelai suami kepada pihak keluarga calon Istri, yang akan digunakan sebagai biaya dalam resepsi pernikahan dan belum termasuk mahar. Due Menre akan menjadi pembahasan utama pada saat proses lamaran dilakukan.

\section{Sejarah Dui Menre}

Sejarah lahirnya Dui Menre menurut beberapa budayawan Sulawesi selatan, bahwasanya uang panai' telah hadir pada masa kerajaan Bone dan Gowa - Tallo. Pada masa itu para pria yang ingin meminang gadis keluarga kerajaan ataupun para bangsawan, diwajibkan untuk menyediakan semacam sesajian sebagai tanda bukti keseriusan dan kemampuan sang pria dalam memberikan kemakmuran dan kesejahteraan kepada sang istri dan anaknya kelak. Selain sebagai tanda bukti keseriusan dan kemampuan sang pria, juga sekaligus sebagai bentuk kehormatan atau penghargaan sosial kepada sang wanita yang 
notabenenya berasal dari kalangan ningrat.

Melihat realitas pernikahan adat bugis saat ini, nampaknya telah terjadi pergeseran nilai dan makna dui menre bagi masyarakat bugis. Secara sadar ataupun tidak, dui menre kini dijadikan sebagai ajang perburuan gengsi sosial (social prestige). Jika dulu siri' (malu) ditujukan kepada hal yang esensial - dengan dui menre yang tinggi, sang pria berfikir dua kali untuk bercerai dan sang wanita menjaminkan dirinya untuk tidak berkhianat, maka sekarang siri' (malu) hanya ditujukan kepada hal yang simbolis - nominal dui menre tanpa ada jaminan apapun.

Budaya itu berubah sejak seorang laki-laki (tidak dari kasta bangsawan) mencoba menikahi seorang perempuan bangsawan. Pihak keluarga tentu saja menolak karena mereka beranggapan bahwa laki-laki itu merendahkan mereka karena melamar. Mereka khawatir nasib anak mereka akan sama dengan perempuan yang lainnnya sehingga pihak keluarga meminta bukti keseriusan pada laki-laki atas niatannnya datang melamar. Jadi pada saat itu orangtua si gadis ini mengisyaratkan kepada sang pemuda kalau ia ingin menikahi anak gadisnya dia harus menyediakan mahar yang telah ditentukannya. mahar yang diajukan sangatlah berat sang pemuda harus menyediakan material maupun non material. hal ini dilakukannya untuk mengangkat derajat kaum wanita pada saat itu. Sang pemuda rela merantau bertahun-tahun untuk mencari dui menre demi pujaan hatinya ia bekerja keras agar dapat menghasilkan tabungan untuk meminang gadis pujaannya. Setelah mencukupi persyaratan yang diajukan oleh orang tua si gadis sang pemuda pun kembali meminang gadis pujaannya dan pada saat itu melihat kesungguhan hati sang pemuda orang tua si gadis merelakan anaknya menjadi milik sang pemuda tersebut.

Adanya persyaratan yang diajukan memberikannya sebuah pelajaran yakni menghargai wanita karena memang sangat mahal untuk disakiti apalagi sang pemuda itu mendapatkan istrinya dari hasil jeri payahnya sendiri itulah sebabnya ia begitu menyanyangi istrinya. Jadi mahalnya dui menre suku bugis bukan seperti barang yang diperjual belikan, tapi sebagai bentuk penghargaan kepada sang wanita, jadi ketika tersirat dihati ingin bercerai dan menikah lagi maka sang pemuda akan berpikir berkali-kali untuk melakukannya karena begitu sulitnya ia mendapatkan si gadis ini.

Oleh karena perkawinan mempunyai arti yang demikian pentingnya, maka pelaksanaannya senantiasa dimulai dan seterusnya disertai dengan berbagai-bagai upacara lengkap dengan sesajen-sesajennya. Bahkan arwah-arwah leluhur kedua belah pihak diharapkan juga merestui kelangsungan rumah tangga mereka. 


\section{Strafikasi Dui Menre}

1. Status sosial

Masyarakat beranggapan bahwa keberhasilan mematok dui menre dengan jumlah yang tinggi adalah suatu kehormatan tersendiri. Karena tingginya dui menre akan berdampak kemeriahan, kemegahan, dan banyaknya tamu undangan dalam pernikahan tersebut. Jika jumlah dui menre yang diminta mampu dipenuhi oleh calon mempelai pria, hal tersebut akan menjadi (kehormatan) bagi pihak perempuan. Kehormatan yang dimaksudkan disini adalah rasa penghargaan yang diberikan oleh pihak calon mempelai pria kepada perempuan yang ingin dinikahinya, dengan memberikan pesta yang megah untuk pernikahan melalui dui menre.

Secara tradisional masyarakat Wajo, mengenal adanya stratifikasi social berlandaskan pada tingkat kebangsawanan. Pada zaman dahulu masyarakat Wajo tersusun dalam tiga lapisan utama, terdiri dari kaum bangsawan sebagai lapisan teratas. Berikutnya lapisan yang kebanyakan yang disebut dengan tau maradeka (orang yang merdeka) menempati lapisan menengah, sedangkan lapisan paling bawah terdiri atas golongan ata (hamba sahaya, budak). Untuk memperbaiki status social, masyarakat wajo terkadang memanfaatkan jalur pernikahan sebagai metode pengubah nasib (achieved status).

Dalam konteks masyarakat modern sekarang, indicator yang menjadi penentu status sosial seseorang dapat ditinjau dari latar pendidikan, kekayaan dan kedudukan (politik). Adapun gelar kehormatan (kebangsawanan) kini telah bergeser dan tak lagi masuk perhitungan dalam penentuan strata sosial seseorang. Artinya, apapun gelar kebangsawanan yang melekat pada seseorang itu tidak akan mempengaruhi status dan peran sosialnya ditengah masyarakat modern - terkhusus masyarakat kota.

Namun sebagian besar masyarakat kita terkhusus keluarga sang mempelai wanita masih terjebak dalam upaya mematok standar dui menre hanya dengan mengandalkan status kebangsawanannya. Sehingga dengan status tersebut mereka menerapkan standar dui menre yang tinggi. Selain itu, kebanyakan dijadikan alat untuk mendongkrak strata sosialnya karena dengan begitu pihak terkait dapat mengadakan sebuah pesta pernikahan yang besar dan mewah dan menjadikannya simbol elit.

\section{Status Ekonomi}

Semakin kaya perempuan yang akan dinikahi, maka semakin tinggi pula dui menre yang harus diberikan oleh calon suami kepada pihak keluaga calon istri dan begitu sebaliknya, jika calon istri tersebut hanya keluarga dari umunya kelas ekonomi menengah kebawah maka jumlah dui menre relative kecil.

Dui menre yang dibutuhkana dalam pesta pernikahan, memang adakalanya dapat membawa akibat buruk, terutama bagi pihak keluarga laki-laki di samping memberikan 
jumlah uang dui menre, mak juga harus menyediakan jumlah uang yang akan diperlukannya sendiri. Jadi berarti bahwa pihak pria harus menyediakan jumlah uang belanja paling tidak dua kali jumlah anggara belanja yang butuhkan oleh keluarga.

Menurut Dahlia, informan berumur kurang lebih 37 tahun yang diwawancara, saat ini nominal uang naik yang termasuk rata-rata (standar) berkisar antara 25 sampai 30 juta rupiah. "Bahkan untuk golongan bangsawan bisa sampai 100 juta!" serunya. Di samping dari status sosial, indikator besar kecilnya uang naik bisa dilihat dari kemewahan pesta pernikahan. Masyarakat bugis yang biasanya dari golongan wiraswasta (pebisnis) dan pemangku jabatan tinggi di suatu instansi, mengadakan resepsi di tiga tempat; rumah mempelai laki-laki, rumah mempelai perempuan, dan di gedung. Pemilihan gedung sebagai tempat dilangsungkannya resepsi pernikahan juga bisa dijadikan ukuran kaya tidaknya keluarga yang mengadakan pesta tersebut. Jika resepsinya di hotel mewah, maka sudah pasti ia orang kaya, dan dui menrenya tanpa perlu orang lain tahu berapa tepatnya nominalnya, sudah tentu besar. Dui menre memang adalah gengsi sosial demi menjaga martabat keluarga karena adanya pertimbangan akan persepsi orang lain di luar keluarga kedua mempelai.

3. Jenjang Pendidikan

Faktor lain yang mempengaruhi tingginya jumlah Dui menre yang harus dikuluarkan adalah tinggi rendahnya jenjang pendidikan calon istri. Semaking tinggi tingkat pendidikan perempuan maka semakin tinggi pulah uang belanja yang harus diberikan dan jika tidak memberikan dalam jumlah yang tinggi maka akan menjadi buah bibir di masyarakat.

Kebiasaan orang tua Wajo dahulu menikahkan anaknya dibawah umur, lambat laun mulai berubah seiring dengan makin meningkatnya tingkat pendidikan baik orang tua dan maupun anak, melihat dari segi tingkat pendidikan anak maka semaking tinggi juga Dui menre-nya.

\section{TINJAUAN HUKUM ISLAM TERHADAP DUI MENRE DI KAB. WAJO}

\section{A. Kedudukan Dui Mernre dan Fungsinya dalam Pernikahan Adat Bugis di Kabupaten Wajo}

1. Kedudukan Dui Menre

Masyarakat suku Bugis dan khusunya kabupaten Wajo menganggap bahwa pemberian dui menre dalam pernikahan adat mereka adalah suatu kewajiban yang tidak bisa diabaikan. Itu dapat disaksikan saat proses negosiasi antara utusan keluarga dari pihak laki- laki dan utusan dari pihak keluarga perempuan, mereka lebih fokus membahas jumlah dui menre dan tidak mempermasalahkan jumlah mahar yang diserahkan oleh suami.

Masyarakat Bugis Wajo beranggapan bahwa kewajibatan memberikan dui menre sama seperti kewajiban memberikan mahar. Hal ini terjadi karena antara dui menre dan mahar 
adalah merupakan satu kesatuan yang tidak dapat dipisahkan walaupun mereka lebih terfokus pada dui menre saja. Seorang calon suami yang memberikan dui menre kepada pihak keluarga calon istri bukan berarti secara langsung telah memberikan mahar. Karena dui menre tersebut belum termasuk mahar.

\section{Fungsi dan Tujuan Dui Menre}

Secara sederhana, dui Menre dapat diartikan sebagai uang belanja, yakni sejumlah uang yang diberikan oleh pihak mempelai laki-laki kepada pihak keluarga mempelai perempuan. Dui menre tersebut ditujukan untuk belanja kebutuhan pesta pernikahan. Satu hal yang harus dipahami bahwa dui menre yang diserahkan oleh calon suami diberikan kepada orang tua/wali calon istri.

Penggunaan yang dimaksud adalah membelanjakan untuk keperluan pernikahan mulai dari penyewaan gedung atau tenda, menyewa grup musik atau masyarakat setempat menyebutnya electone, membeli kebutuhan konsumsi dan semua yang berkaitan dengan jalannya resepsi pernikahan. Adapun sisa dui menre yang tidak habis terpakai akan dipegang oleh orang tua. Akan tetapi pada umumnya semua uang tersebut akan habis terpakai untuk keperluan pesta pernikahan. Terkadang pula mempelai perempuan akan mendapat sebagian dari total dui menre tersebut jika tidak habis terpakai. Pembagiannyapun diserahkan kepada orang tua atau walinya dan hal ini menjadi otoritas para orang tua/wali.

3. Tinjauan Hukum Islam Terhadap Tradisi Dui Menre Pada Masyarakat Bugis di Kabupaten Wajo

Dalam pandangan Islam, Dui Menre adalah sebagai penghormatan yang tulus terhadap perempuan, yang pada zaman Jahiliyah kedudukan mereka tidak lebih dari harta atau benda yang bias diperjual belikan. Dan diwajibkannya laki-laki membayar mahar kepada perempuan adalah sebagai tanda ketinggian kedudukan mereka, dan sebagai uang muka dari sebuah bangunan cinta kasih.

Pernikahan adalah Sunnatullah yang bertujuan menghasilkan kehidupan rumah tangga yang baik. Akan tetapi, jika tujuan yang diniatkan pada awalnya buruk maka mungkin saja akan menimbulkan banyak masalah dalam pernikahan yang diwujudkan. Pernikahan merupakan sunnah Rasul maka dalam menetapkan mahar pun harus mengikuti apa yang ditetapkan oleh Rasul dalam sunnahnya. Manusia tidak boleh membuat aturan sendiri yang berdasarkan hawa nafsunya, akan tetapi manusia dituntut untuk mengikuti apa yang ditetapkan oleh Allah dalam Al-Qur'an dan Rasulullah di dala m hadis-hadisnya.

Pelaksanaan pemberian dui menre walaupun tidak tercantum dalam hukum Islam, hal ini tidak bertentangan dengan Syari'at dan tidak merusak akidah karena salah satu fungsi dari 
pemberian dui menre adalah sebagai hadiah bagi mempelai perempuan untuk bekal kehidupannya kelak dalam menghadapi bahtera rumah tangga.

Agama Islam sebagai agama rahmat li'l alamin tidak mensayriatkan penentuan mahar yang memberatkan pihak laki-laki untuk melangsungkan pernikahan, demikian pula dui menre dianjurkan agar tidak memberatkan bagi pihak yang mempunyai niat suci untuk menikah. Pernikahan sebagai sunnah Nabi hendaknya dilakukan dengan penuh kesederhanaan dan tidak berlebih-lebihan sehingga tidak ada unsur pemborosan di dalamnya karena Islam menentang sikap yang berlebih-lebih.

Pemberian dui menre di Kabupaten Wajo merupakan suatu kewajiban yang harus dipenuhi dan biasanya dalam jumlah yang tidak sedikit. Namun demikian dari hasil wawancara diperoleh gambaran bahwa para lelaki yang ingin menikahi wanita dari suku Bugis merasa tidak terbebani dengan nilai dui menre yang relatif tinggi karena dalam penentuan jumlah dui menre itu terjadi proses tawar menawar terlebih dahulu sampai tercapai sebuah kesepakatan sehingga masih dalam jangkauan kemampuan pihak laki-laki untuk memenuhi dui menre yang disyaratkan. Selain itu para lelaki memang telah mengetahui sebelumnya akan adat tentang dui menre tersebut sehingga mereka telah mempersiapkan segalanya sebelum melangkah ke jenjang yang lebih serius.

Hukum Islam mengakui adat sebagai sumber hukum karena sadar akan kenyataan bahwa adat kebiasaan telah mendapatkan peran penting dalam mengatur lalu lintas hubungan tata tertib sosial di kalangan anggota masyarakat. Adat kebiasaan berkedudukan pula sebagai hukum yang tidak tertulis dan dipatuhi sesuai dengan kesadaran hukum mereka. Dan pada akhirnya Adat kebiasaan yang tetap sudah menjadi tradisi dan telah mendarahdaging dalam kehidupan masyarakat.

Tidak dapat dipungkiri seperti kata pepatah dimana bumi dipijak di situ langit dijunjung, hal ini dapat dilihat pada masyarakat Wajo dengan adanya kewajiban dui menre bagi suku Bugis, mau tidak mau masyarakat Wajo harus tunduk pada aturan adat yang sudah dibangun sejak lama. Ini akan menjadi masalah ketika aturan ini tidak diwajibkan dalam agama namun adat mewajibkan hal tersebut, di sini adat terlihat lebih kuat dari pada agama, yang seharusnya agama lebih dijunjung tinggi dari pada adat.

Dalam kehidupan masyarakat banyak sekali kegiatan dan aturan adat yang berasal dari nenek moyang. Misalnya, dui menre tradisi ini telah turun temurun dari generasi ke generasi yang tetap dipelihara hingga sekarang. Dalam aktivitas praktis manusia, tradisi menjadi sebuah hal yang begitu penting. Fungsi tradisi memberi pedoman untuk bertindak dan memberi individu sebuah identitas.

Adat dan kebiasaan selalu berubah-ubah dan berbeda-beda sesuai dengan perubahan zaman dan keadaan. Realitas yang ada dalam masyarakat berjalan terus menerus sesuai 
dengan kemaslahatan manusia karena berubahnya gejala sosial kemasyarakatan. Oleh karena itu, kemaslahatan manusia itu menjadi dasar setiap macam hukum. Maka sudah menjadi kewajaran apabila terjadi perubahan hukum karena disebabkan perubahan zaman dan keadaan serta pengaruh dari gejala kemasyarakatan itu sendiri. Sebagaimana kaidah fiqhiyah berikut:

"Berubahnya fatwa dikarenakan perubahan masa dan tempat."

Perlu ditegaskan bahwa pelaksanaan pemberian dui menre dalam pernikahan adat suku bugis di kabupaten Wajo walaupun sudah menjadi tradisi dan membudaya hal ini tidak bersifat wajib mutlak, dalam artian pernikahan yang dilaksanakan tanpa memberikan dui menre dan hanya memberikan mahar kepada calon mempelai wanita maka pernikahan tersebut dinilai sah menurut hukum Islam, namun secara adat akan dianggap sebagai pelanggaran yang berakibat mendapatkan hinaan dan celaan dari masyarakat.

Fenomena pemberian dui menre pada masyarakat bugis di kabupaten Wajo dalam hukum Islam dapat dikatakan sebagai kebiasaan yang baik yaitu kebiasaan yang dipelihara oleh masyarakat dan tidak bertentangan dengan hukum Islam, tidak mengharamkan sesuatu yang halal, tidak membatalkan sesuatu yang wajib,tidak menggugurkan cita kemaslahatan, serta tidak mendorong timbulnya kemafsadatan.

Tradisi pemberian dui menre juga sesuai dengan asas hukum pernikahan Islam karena di dalamnya terdapat asas kerelaan dan kesepakatan antara pihak mempelai laki-laki dan pihak mempelai perempuan dalam penentuan nilai dui menre.

\section{KESIMPULAN}

Dui menre dalam masyarakat Bugis Wajo adalah sebagai Rukun atau syarat yang harus di penuhi sebelum melakukan upacara pernikahan. Selain itu juga sebagai penghormatan Tradisi suku Bugis, fungsi dui menre adalah sebagai persediaan uang belanja resepsi sebelum dan sampai upacara pernikahan diselenggarakan, dui menre juga membantu membeli keperluan-keperluan untuk memeriahkan upacara pernikahan. Hukum dui menre menurut hukum Islam adalah mubah (boleh) karena kedudukannya adalah sebagai hibah. Pemberian dui menre dalam pernikahan adat Bugis merupakan persyaratan (kewajiban) adat bukan berdasarkan syar'i. Jadi menurut hukum Islam orang boleh memberikan atau tidak memberikan dui menre. Alangkah baiknya jika pelaksanaan adat yang menyangkut tentang Dui Menre tidak menyusahkan setiap masyarakat khususnya mempelai laki-laki, dalam artian Dui menre tidak seharusnya memberatkan bagi pihak laki-laki untuk melaksanakan pernikahan, sekalipun Tinjaun Hukum Islam tidak melarang adanya dui menre. 


\section{DAFTAR PUSTAKA}

Al-Asqolani, Ibn Hajr, Bulughul Maraam, Terjemah Al-Hassan (Bangil: Pustaka Tamaam, 2001)

Al-Hamdani, HSA, Risalah Nikah, Alih Bahasa oleh Agus Salim, cet. ke-1 (Jakarta: Anai, 1985)

Badruddin, Syamsiah, Gaukeng To Wajo'e, (Cet. I Yokyakarta: Leutika Books 2012)

Denada, Aditiya, Uang Panai (Dui Menre) dalam Proses perkawinan (Kajian Sosiologi Masyarakat Desa Sanrangeng Kec. Dua Boccoe Kab. Bone. Skripsi Makassar: Fakultas Ilmu sosial dan Ilmu Univesitas Hasnuddin 2012)

Departemen Agama RI, Kompilasi Hukum Islam di Indonesia, (Jakarta; Direktorat Jenderal Pembinaan Kelembagaan Agama Islam, 1997)

Departemen Agama RI, Pedoman Pembantu Pegawai Pencatat Nikah

Depertemen Agama RI., Al Qur'an dan Terjemahnya, (Jakarta: Proyek Pengadaan Kitab Suci Al-Qur'an Dep. Agama RI. Pelita III 1984)

Ghozaly, Abd. Rahman, Fiqh Munakahat, (Jakarta; Prenada Media, 2003)

Hadikusuma, Hilman, Hukum Pernikahan Indonesia Menurut Pandangan Hukum Adat, Hukum Agama, (Bandung: Mandar Maju, 1990)

Hakim, Rahmad, Hukum Perkawinan Islam (Bandung: Pustaka Setia, 2000)

HAS, Al-Hamdani dkk, Risalah Nikah, (Cet. I Jakarta: Anai, 1985)

Moein, Mengenali Nilai-Nilai Budaya Bugis - Makssar dan siri Pagge (Jakarta: Press, 1988)

Muslim, Abi Hasan, Shohih Muslim, (Surabaya; Al-Hidayah) Juz. I

Saebani, Ahmad Beni, Fiqhi Munakahat, (Jakarta: CV Pustaka Setia, 2001)

Sahabuddin, Sulaiman, Uang Panai Tinggi, (Cet. I Makassar: Leisyah 2016)

Syarifuddin, Amir, Hukum Perkawinan Islam di Indonesia (Antara Fiqh Munakahat dan Undang-undang Perkawinan)

UU, 1/974 Tentang Perkawinan Pasal 1 (Surabaya; Arkola, 1983)

Wasman dan Wardah Nuroniyah, Hukum Perkawinan Islam di Indonesia, (Cet. I Yogyakarta: Teras 2011)

Wignjodipoero, Soerjo, Pengantar dan Asas-Asas Hukum Adat, (Jakarta: Gunung Agung 1983)

Willie koen dkk, Kamus Besar Bahasa Indonesia, (Cet. II. Jakarta: Balai Pustaka, 2002)

Wulansari, Dewi, Hukum Adat Indonesia, (Bandung: Refika Aditama 2010)

Zuhdi, Masjfuk, Masail Fiqhiyyah, (Jakarta: GunungAgung, 1996). 